\title{
Microscopic and Molecular Detection of Camel Anaplasmosis and Piroplasmosis in Banadir region, Somalia
}

\author{
Abdalla MII*, Ahmed AHK ${ }^{2}$ and Hamisi SN ${ }^{3}$ \\ ${ }^{1}$ Abrar Research and Training Centre, Abrar University, Somalia \\ 2 ICRC, Somalia \\ ${ }^{3}$ Vector and Vector Borne Diseases Institute, Tanzania
}

\section{Research Article}

Volume 2 Issue 1

Received Date: December 22, 2016

Published Date: February 20, 2017

*Corresponding author: Abdalla Mohamed Ibrahim, Abrar Research and Training Centre, Abrar University, Somalia, Email: director.artc@abrar.edu.so

\section{Abstract}

The socio-economic importance of dromedary camels (Camelusdromedarius) is unique for Somali community. It has been a rich area of research before the civil war. The present study was planned to investigate piroplasmosis and anaplasmosis in camels from Banadir region of Somalia using microscopical (Blood Film) and molecular (PCR) techniques. A total of 182 camels including semi-intensive dairy camel farms and nomadic (extensive) systems were sampled from three districts in Banadir region between December 2015 and March 2016.The prevalence rate using parasitological and molecular examinations was52.2\% and $54.9 \%$ respectively. In microscopical results, the prevalence rates Varies significantly $(\mathrm{p}<0.05)$ between different production systems, Districts and sexes. However, these differences were not significant after molecular confirmation. Using Kappa test, PCR technique was more sensitive and more specific in determination of piroplasms than conventional blood film method. The prevalence rate of Anaplasma sp. using microscopical examination was13.2\%. Mix-infection of piroplasms and Anaplasma sp. is usual in the present study. The degree of anaemia (PCV\%) in the infected camels was significantly affected ( $p=0.05)$ after molecular confirmation of piroplasmosis. The present paper was to be the first report on camel piroplasmosis and anaplasmosis in Banadir region and may be in whole Somalia.

In conclusion, camel piroplasmosis and anaplasmosis are highly prevalent in camels from Banadir region of Somalia. Further studies in the clinical and economical impact of camel all T\&TBDs is recommended. Moreover, the control measures including effective treatment should be conducted to improve the general condition of Somali camels.

Keywords: Camels; Piroplasmosis; Anaplasmosis; Microscopical; PCR; Somalia

\section{Introduction}

Somalia is the largest dromedary (Camelus dromedarius) population area in the world [1-3]. Most of these animals (3-5 million) are kept by nomadic pastoralists [4]. The economic importance of camels for Somalia is due to food security, hard currency earnings and transport of milk and water as well as social issues. 
Camel is the unique to survive and produce under extreme arid and semi-arid conditions of Somalia. Recently, after some security and political settlement, camels are kept around urban areas such as Banadir region (Mogadishu) as semi-intensive farming system.

Causing serious economical losses tick and tick borne diseases (T \& TBDs) still remain to be a major threat to animal's industry in tropical and sub tropical countries [59] including Somalia [10-13]. The available data on T\&TBDs in Somalia was reported by Schoepf et al., [12] and Hassan et al., [13]. They identified Rhipicephalusevertsi, R. pulchellus, R. Humeralis, R. simus $R$. parvus, Amblyommalepidum, A. gemma, A. varigatum, Hyalommatruncatum and $H$. rufipes from the investigated cattle, sheep and goats with prevalence rate of (29-100\%) piroplasmosis in Lower Juba and Banadir regions of Somalia. The above three genera of hard ticks (Hyalomma, Rhipicephalus and Amblyomm) were also reported from Somali camels $[12,14]$, but the authors believe that they have no role as camel disease vectors. Among the few common diseases affecting camels TBDs are usually neglected [14,15]. The evidence is that very Few literature is available on camel piroplasmosis in the onehumped camel zone, such as Egypt [16], Iraq [17], Iran [18], Sudan [19,20] and KSA [21].

Despite this valuable socio-economic importance of camels in Somalia, scientific data about diseases affecting them was missed after the civil war $[12,14]$. Therefore, this study aims to use microscopical and molecular techniques to investigate the prevalence of camel piroplasmosis and anaplasmosis as a baseline data for T\&TBDs research and control in the country.

\section{Materials and Methods}

\section{Study Area}

Banadir region which located in South-eastern Somalia is one of the eighteen regions of the country. Banadir region itself is coextensive with Mogadishu, the capital city of the country. It consists of seventeen districts. Three of them were included in this study namely Kahda, Deyniile and Yaqshid. These districts are the main camel rearing areas available in the study area.

\section{Study Population}

Adult ( $\geq 2$ years old) one humped camels (Camelus dromedarius) in the above mentioned study area were sampled between December 2015 and March 2016. Both nomadic (extensive camel production system) and camel dairy farms (semi-intensive camel production system) were visited for blood samples collection. A total of 182 camels (133 semi-intensive dairy farm camels system and 49 nomadic/extensive systems) were included in the present study. Most of them are female (176 head), and only 6 head of male were sampled in the investigated herds or dairy camel farms.

\section{Blood Samples}

A total of 182 heparinized camel's blood samples were collected from jugular vein. The samples were transported to Abrar Research and Training Centre (ARTC) in Abrar University, Somalia for the following laboratory work:

Thin dried fixed Giemsa's stained blood smears were prepared and examined microscopically for presence of any extracellular or intracellular blood parasites including piroplasms and Anaplasma spp.

1. Photos of the detected parasites were captured directly from microscope eye piece using digital camera (Sony, 16.1 MP) and stored in computer.

2. The degree of anaemia was measured by the conventional haematocrit centrifugation technique and PCV\% of the tested camels was reported.

3. Drop of whole blood from each sample was spotted on filter paper (Whatman No.4). The dried blood spots were stored in $-20^{\circ} \mathrm{C}$ before sent for molecularly analyses of camel piroplasmosis in Vector and Vector Borne Diseases Institute (VVBDI), Tanzania using Polymerase Chain Reaction (PCR).

\section{Extraction of the DNA}

More than 10 micro-punches of $1.2 \mathrm{~mm}$ each were taken from the preserved dry spot of whole blood on the filter paper. To reduce the chances of missing out piroplasm DNA punches were done randomly and keep on sterile $1.5 \mu$ Leppendorf tube. The well cleaned Harris $1.2 \mathrm{~mm}$ micro-punch (Whatman Biosciences Ltd.) was used. To prevent contamination between samples, the punch were cleaned after every sample using a $70 \%$ ethanol then punch were used to cut a clean filter paper before using it on the next sample.

Total DNA was isolated by fastest version of the chelex extraction technique briefly $200 \mu \mathrm{l}$ volume of solution with Chelex 100 (Sigma-Aldrich, St. Louis, USA) (final concentration $20 \%$ ) were added into the $1.5 \mu \mathrm{L}$ eppendorf tube with samples boiled for 10 min and preserved in -20 


\section{Open Access Journal of Veterinary Science \& Research}

${ }^{\circ} \mathrm{C}$ and were spanned at $13000 \mathrm{rpm}$ for 3 minutes before using $2 \mu \mathrm{L}$ of supernatant for PCR.

\section{Polymerase Chain Reaction (PCR)}

Extracted DNA samples were subjected to Internal Transcribed Spacers (ITS) 1 Polymerase Chain Reaction (PCR) amplification. Presence of piroplasms were characterized by PCR using the primer Bab-sp-F (GTTTCTGCCCCATCAGCTTGAC) and Bab-sp-R (CAAGACAAAAGTCTGCTTGAAAC) was used as the forward and reverse primers, respectively $[22,18]$. Both primers were supplied by Pioneer Corporation. The PCR amplifications were performed in a total reaction volume of $25 \mu \mathrm{l}$ containing $0.5 \mu \mathrm{lof} 10 \mathrm{pM}$ of each primer, $12.5 \mu \mathrm{l}$ of one 2x master mix (BioLab. New England), 9.5 $\mu$ l of PCR water and $2 \mu$ lof each DNA template. PCR amplifications were performed with a thermal cycler (Gene Amp 9700 PCR system, Applied Biosystems). Amplification condition were initial denaturation at $94^{\circ} \mathrm{C}$ for $1 \mathrm{~min}$ and 30 seconds , followed by 45 cycles of $94^{\circ} \mathrm{C}$ for $20 \mathrm{~s}, 65^{\circ} \mathrm{C}$ for $30 \mathrm{~s}$, followed by $68^{\circ} \mathrm{C}$ for $30 \mathrm{~min}$, and final extension at $68^{\circ} \mathrm{C}$ for $10 \mathrm{~min}$.

To ensure that results were not biased by false positives during repeated PCRs, negative controls in which DNA templates were replaced with sterile water as well as positive control DNA were included in all PCR reactions. The amplified PCR product was electrophoresed on a 1.5\% agarose gel in 1X TBE. Quick Loading100bp DNA ladder (BioLab, New England) was included on each gel, stained by Ethidium bromide, run at $100-120 \mathrm{~V}$ for $60 \mathrm{~min}$ and final visualized in Uvidock (Cambridge, UK).

\section{Data Management and Analysis}

Data were stored in a Microsoft ${ }^{\circledR}$ Excel spread sheet for Windows $^{\circledR} 2007$ before transferred to SPSS sheet for Windows ${ }^{\circledR}$ version 20 . The differences were considered statistically significant when $\mathrm{p}<0.05$.

\section{Results}

\section{Microscopical Prevalence of Camel Piroplasmosis}

Piroplasms were detected microscopically in the Giemsa's stained blood films of $52.2 \%$ of the examined camels (table 1). As presented in table 2, the prevalence rate was significantly $(\mathrm{p}=0.045)$ higher $(56.4 \%)$ in semiintensive dairy farm system than the nomadic camels $(40.8 \%)$. Kahda district revealed the highest microscopical prevalence rate $(59.7 \%)$ with statistically significant $(\mathrm{p}=0.050)$ variation from Deyniile $(51.7 \%)$ and Yeqshid (30.4\%) Districts (Table 1). Different shapes of piroplasms were presented in plat 1 as well as hyperparasitaemia in plate 2 .

\section{Molecular Prevalence of Camel Piroplasmosis}

Babesia DNA was detected molecularly in the extracted blood of $54.9 \%$ of the examined camels (table 1).In PCR technique, Extensive (nomadic) system showed higher prevalence rate but without any statistically significant $(\mathrm{p}=0.061)$ differences (Table 2$)$. Without any statistically significant $(\mathrm{p}=0.237)$ variations, Yeqshid District revealed the highest molecular prevalence rate $(60.9 \%)$ followed by Deyniile (59.8\%) and Kahda (47.2\%) Districts (Table 1). The bands of Babesia DNA were presented in plate 3.

\begin{tabular}{|c|c|c|c|}
\hline \multirow{2}{*}{ District } & \multirow{2}{*}{ N (\%) } & \multicolumn{2}{|c|}{ Prevalence n(\%) } \\
\cline { 3 - 4 } & $87(47.8)$ & $45(51.7)$ & PCR \\
\hline Deyniile & $23(12.6)$ & $7(30.4)$ & $14(69.8)$ \\
\hline Yeqshid & $72(39.6)$ & $43(59.7)$ & $34(47.2)$ \\
\hline Kahda & $182(100)$ & $95(52.2)$ & $100(54.9)$ \\
\hline Total & & 0.050 & 0.237 \\
\hline
\end{tabular}

Table 1: Prevalence of camel piroplasmosis in the investigated Districts.

\begin{tabular}{|c|c|c|c|}
\hline \multirow{2}{*}{ District } & \multirow{2}{*}{ N (\%) } & \multicolumn{2}{|c|}{ Prevalence n(\%) } \\
\cline { 3 - 4 } & $49(26.9)$ & Blood film & PCR \\
\hline Extensive & $133(73.1)$ & $20(40.8)$ & $68(65.3)$ \\
\hline Semi-intensive & $182(100)$ & $75(56.4)$ & $100(54.9)$ \\
\hline Total & $95(52.2)$ & 0.061 \\
\hline
\end{tabular}

Table 2: Camel Piroplasmosis in different camel production system. 


\section{Prevalence of Camel Piroplasmosis in Different Sexes}

Piroplasms were not detected in the tested males microscopically (Table 3). However, $66.7 \%$ of them showed DNA of Babesia in PCR technique without any significant $(\mathrm{p}=0.439)$ statistically variation from the prevalence rate in females (Table 3 ).

\begin{tabular}{|c|c|c|c|}
\hline \multirow{2}{*}{ Sex } & \multirow{2}{*}{$\mathbf{N}$} & \multicolumn{2}{|c|}{ Prevalence n (\%) } \\
\cline { 3 - 4 } & & Blood film & PCR \\
\hline Male & $\mathbf{6}$ & $0(0.0)$ & $4(66.7)$ \\
\hline Female & $\mathbf{1 7 6}$ & $95(54.0)$ & $96(54.5)$ \\
\hline Total & $\mathbf{1 8 2}$ & $95(52.2)$ & $100(54.9)$ \\
\hline & & $\mathbf{0 . 0 1 1}$ & $\mathbf{0 . 4 3 9}$ \\
\hline
\end{tabular}

Table 3: Prevalence of camel piroplasmosis in different sexes.

\section{Level of agreement between Microscopical and molecular tests}

PCR technique detected more infection (54.9\%) than blood film technique (52.2\%). PCR technique detected
$48(55.2 \%)$ and 52(54.7\%) out of the 87 negative and 95 positive samples microscopically, respectively (Table 4). The level of agreement between the two techniques is very poor $(\mathrm{Kappa}=0.004)$.

\begin{tabular}{|c|c|c|c|c|}
\hline & & \multicolumn{2}{|c|}{ PCR n (\%) } & \multirow{2}{*}{ Total } \\
\hline \multirow{3}{*}{ Blood Film n (\%) } & & $\mathrm{N}$-ve & P+ve & \\
\hline & $\mathrm{N}$-ve & $39(44.8)$ & $48(55.2)$ & $87(100)$ \\
\hline & P+ve & $43(45.3)$ & $52(54.7)$ & 95(100) \\
\hline \multicolumn{2}{|c|}{ Total } & $82(45.1)$ & $100(54.9)$ & $182(100)$ \\
\hline
\end{tabular}

Table 4: The level of agreement between the two techniques using Kappa test.

\section{PCV of the Investigated Camels}

The mean PCV\% of the tested camels was $(27.7 \pm 3.3 \%)$ with $37 \%$ and $18 \%$ as maximum and minimum PCV values respectively. No significant differences $(\mathrm{p}>0.05)$ between the compare means of the infected $(27.68 \pm$
$3.0 \%)$ and non-infected $(27.8 \pm 3.5 \%)$ camels. However, $26 \%$ and $63 \%$ of the PCR positive samples recorded lower range of $17-25 \%$ and $26-30 \%$ respectively with statistically significant ( $\mathrm{p}=0.05)$ variation (Table 5).

\begin{tabular}{|c|c|c|c|c|c|c|}
\hline \multirow{3}{*}{ PCV\% range } & \multicolumn{6}{|c|}{ Piroplasmosis Result } \\
\hline & \multicolumn{3}{|c|}{ Blood Film n(\%) } & \multicolumn{3}{|c|}{ PCR } \\
\hline & $\mathrm{N}$ & -ve & $+v e$ & $\mathrm{~N}$ & -ve & $+\mathrm{ve}$ \\
\hline $17-25$ & 46 & $25(54.3)$ & $21(45.7)$ & 46 & $20(43.5)$ & $26(56.5)$ \\
\hline $26-30$ & 105 & $44(41.9)$ & $61(58.1)$ & 105 & $42(40.0)$ & $63(60)$ \\
\hline 31-38 & 31 & $18(58.1)$ & $13(41.9)$ & 31 & $20(64.5)$ & $11(34.5)$ \\
\hline Total & 182 & $87(47.8)$ & $95(52.2)$ & 182 & $82(45.1)$ & $100(54.9)$ \\
\hline p-value & \multicolumn{3}{|c|}{0.17} & \multicolumn{3}{|c|}{0.05} \\
\hline
\end{tabular}

Table 5: The effect of piroplasmosis on PCV\% range of Camels. 
Microscopical Prevalence of Camel observed microscopically in the Giemsa's stained blood Anaplasmosis films of $13.2 \%$ of the examined camels. They are usually seen as mixed infection with piroplasms in the infected

Anaplasma like organism of both species (Anaplasmamarginale and Anaplasmacentrale) were camels as demonstrated in plate 1 and plate 2 .



Plate 1: Piroplasms with different shapes and Anaplasma sp. (arrows) in Giemsa's stained blood of camel.








Plate 3: Agarose gel (1.5\%) electrophoresis of amplified DNA from Babesia. Lane M: DNA ladder (100bp). Lanes 37: Positive control, Lane 38: Negative control. Positive product showed clear band in 400bp (All Lanes except sample No 16).

\section{Discussion}

In spite of having the largest counts of camels, the economical value of them is still unrecognized in Somalia. That is because of lack of scientific data as a concrete base for continuous health care. T\& TBDs still remain to be a major threat to animal's industry by causing serious economical losses in tropical and sub tropical countries $[5,9]$, and Somalia is not an exception.

The prevalence of camel piroplasmosis in this study was higher than the available reports from Sudan [19], KSA [21], Egypt [16], Iran [18] and Iraq [17]. However, it is lower than our recent data from Gadarif State of Sudan [20], although, the same diagnostic techniques were used. There is no clear picture of ticks mapping in Somalia $[11,13]$, but their prevalence may be lower in Banadir region of Somalia than in the Gadarif State of Sudan [8]. In contrast with the believes of Cankovic and Abdurahman and Bornstein $[12,14]$, the results of the present study could be considered as evidence that ticks are also serious disease vectors in Somali camels. The prevalence rate of camel piroplasmosis in this study found to be almost similar to that reported in Somali boran cattle [11].

The results of this study revealed that PCR is more sensitive and more specific for detection of camel piroplasmosis than conventional blood film technique.
Similar observations were reported in Iran [18], Iraq [17] and Sudan [20]. In this study, the level of agreement between the two diagnostic tests was very poor. That is because all intracellular Anaplasma like organisms that has been diagnosed as piroplasms were excluded by the specific Babesia primer used in this study. This also helps us to explain the poor level of agreement reported in our previous report from Sudanese camels using the same diagnostic techniques. Moreover, the use of other specific primer for Theileria sp. will be useful in our next steps. It worth mentioning that molecular confirmation of camel anaplasmosis also is to be continued to complete the picture of Somali camels TBDs research.

The present study revealed that more than half of camels of the investigated area were carriers of piroplasmosis. Thus they are a source of infection for the co-herded equines, because camels are usually found to be infected by equine piroplasms $[19,17,23,24]$.

Based on the results of molecular confirmation in this study, there were no significant variations $(p>0.05)$ in the prevalence of camel piroplasmosis between neither the different production systems nor the different districts. The significant variation $(\mathrm{p}<0.05)$ in the different sexes reported in the present study could not be considered because the number of males is incomparable to the tested females. 


\section{Open Access Journal of Veterinary Science \& Research}

The range of PCV\% in the present study was significantly affected by piroplasmosis and anaplasmosisal though camels are known to be tolerant to various infections. That is may be because of hyperparasitaemia of piroplasms as well as the usual mixinfection with Anaplasma sp.

Based on the results of this study, piroplasmosis and anaplasmosis could be responsible for morbidity and mortality of Somali camels. Therefore, treatment interpretation will be important to improve camel production and productivity in Somalia.

\section{Acknowledgment}

The authors would like to thank Abrar University, Somalia for funding. We are also grateful to VVBDI, Tanzania, for molecular work. Special thanks to Dr. ImnaMalele, Mr. Peter Paul and Miss Delphina.

\section{Conflict of Interest}

The authors declare that they have no conflict of interest regarding the publication of this article.

\section{References}

1. Wilson RT, Araya A, Melaku A (1990) The one humped camel. An analytical and annotated bibliography. The United Nations Sudano Sahelian Office (UNSO), Technical paper series 3.

2. Anonymous (1988) Somali Livestock Statistics 1987/1988. Department of Planning and Statistics. Ministry of Livestock, Forestry and Range. Mogadishu, Somalia.

3. Anonymous (1981) Annual report of the Veterinary Laboratory, Kismayo. Department of Veterinary Services, Ministry of Livestock, Forestry and Range, Somalia.

4. Baumann MPO, Zessin KH (1992) Reproductivity and health of camels (Camelus dromedarius) in Somalia: Associassion with Trypanosomosis and Brucellosis. Trop Anim Health Prod 24: 145-156.

5. Hoogstraal H (1956) African Ixodidae Volume I, Ticks of the Sudan. Department of Medical Zoology, US Naval Medical Res. Unit No 3 Cairo, Egypt.

6. Soulsby EJL (1986) Helminths, Arthropods \& Protozoa of Domesticated Animals. 7th (Edn.) Bailliere
Tindall, London.

7. El Hussein AM, Majid AM, Hassan SM (2004) The Present Status of Tick-Borne Diseases in the Sudan. Ar- chives de l'Institut Pasteur de Tunis 81(5): 31-34.

8. Hassan SM, Salih DA (2009) Bibliography with Abstracts, Ticks and Tick-borne Diseases in the Sudan. $1^{\text {st }}(E d n$.$) Central Laboratory, Ministry of$ Science and technology, Khartoum.

9. Shommein AM, Osman AM (1987) Diseases of camels in the Sudan. Rev sci tech Off int Epiz 6(2): 481-486.

10. Pegram RG (1976) Ticks (Acarina, Ixodoidae) of the northern regions of the Somali Democratic Republic Bull Entemol Res 66(2): 345-363.

11. Schoepf K, Mohamed HAM, Katende JM (1984) Observation on blood borne parasites of domestic livestock in the lower Juba region of Somalia. Trop Anim Hlth Prod 16(4): 227-232.

12. Cankovik M (1984) Technical report on Parasitology. Field document Rome: UNDP/FAO; SOM/87/006.

13. Hassan AA, Ibrahim AM, Mohamed RH, Haji Aden, $\mathrm{H}$ (2013) Preliminary Assessment of Goat Piroplasmosis in Benadir Region, Somalia. Open Journal of Veterinary Medicine 3: 273-276

14. Abdurahman Osh, Bornstein S (1991) Diseases of camels in Somalia and Prospect for Better health. Nomadic peoples 29: 104-112.

15. Köhler-Rollefson I, Musa BE, FadlAchmed M (1991) The camel pastoral system of the southern Rashaida in eastern Sudan. Nomadic Peoples 29: 68-76.

16. Abd-Elmaleck BS, Abed GH, Mandourt AM (2014) Some Protozoan Parasites Infecting Blood of Camels (Camelus dromedarius) at Assiut Locality, Upper Egypt. J Bacteriol Parasitol 5: 184.

17. Jasim HJ, Azzal GY, Othman RM (2015) Conventional and molecular detection of Babesiacaballi and Theileriaequi parasites in infected camels in south of Iraq. Bas J Vet Res 14(2): 110-121.

18. Khamesipour F, Doosti A, Koohi A, Chehelgerdi M, Mokhtari Farsani A, et al. (2015) Determination of the presence of Babesia DNA in blood samples of cattle, camel and sheep in iran by pcr. Arch Biol Sci Belgrade 
67 (1): 83-90.

19. Abdelrahim IA, Ismail AA, Abdelmajid AM, Siddig AM, Ibrahim AM, et al. (2009) Detection of Babesiacaballi in the one-humped Camel (Camelius dromedarius) Using the Reverse Line Block RLB) in Sudan. Sudan J Vet Res 24: 69-72.

20. Ibrahim AM, Hassan AA, Nyingilili HS (2016) Microscopic and Molecular Detection of Camel Piroplasmosis in Gadarif State, Sudan. Veterinary Medicine International, Veterinary Medicine International, 2017 9345231: 5.

21. Swelum AA, Ismael $\mathrm{AB}$, Khalaf $\mathrm{AF}$, Abouheif $\mathrm{MA}$ (2014) Clinical and laboratory findings associated with naturally occurring babesiosis in dromedary camels. Bull Vet Inst Pulawy 58(2): 229233.
22. Hilpertshauser H, Deplazes P, Schnyder M, Gern L, Mathis A (2006) Babesia spp. identified by PCR in ticks collected from domestic and wild ruminants in southern Switzerland. Appl Environ Microbiol 72(10): 6503-6507.

23. Salim B, Bakheit MA, Kamau J, Sugimoto C (2013) Current status of equine piroplasmosis in the Sudan. Infection, Genetics and Evolution 16: 191-199.

24. Hosseini SR, Taktaz-Hafshejani T, Khamesipour F (2017) Molecular detection of Theileriaequi and Babesia caballi infections in horses by PCR method in Iran, Kafkas Universitesi Veteriner Fakultesi Dergisi Journal 23 (1): 161-164 